\title{
A Study on Consumer Preferences for E Shopping with reference to Bahraini Consumers
}

\author{
Dr M Nishad Nawaz MBA., MHRM., M.Phil.,Ph.D. c \\ College of Business Administration, Kingdom University, Bahrain. \\ Email Id: nnawazm@gmail.com
}

Ms Wafa Yaqoob Ali Alajmi BS

College of Business Administration, Kingdom University, Bahrain.

Email Id: wafooy-10@hotmail.co.uk

\begin{abstract}
Technology based Internet has shortened the gap between continents, countries, cities, towns and villages and people. Different parts of the people have similar tastes, perceptions, styles and accessibility. Now Online shopping has opened the doors of globalization as it facilitate all the information about the product from anywhere around the world and it can be accessed 24/7. Therefore organizations have changed their selling and buying strategy. An even consumer preferences also has changed in terms of choices, quality, services, selling and buying. The main reason behind this is that, most of the electronic devices apps are well connected to the internet. Therefore, consumers are showing very enthusiastic behavior to buy and sell their chosen product. Keeping these benefits in their mind consumers are acting very smart and showing lots of interest to do online shopping, why because its saves time, easy payment and it will display many options to choose best of the best of his choice of product.

The present study is to know which factors are influences Bahraini consumers to go for E shopping. The study further discloses that which professions are showing interest in E shopping in Bahrain. The Researchers dropped their suggestions for $\mathrm{E}$ tailors and consumers so that it can be implemented for further success.
\end{abstract}

Key words: E shopping, consumers, payment mode, purchase mode.

\section{Introduction}

In present scenario, consumers and organizations are carrying out extensive and rapidly increasing volumes of business on the internet. The online shopping/ E shopping is method of electronic commerce for conducting businesses [end to end process] it is shifted from real market to digital market. At present all businesses are doing business over the internet. It allows consumers to directly buy goods/sell/get services over the internet by using the web browser. Michael Aldrich made invention and introduced online shopping in 1979. Day by day internet usage is increasing, so also the prospect of online marketing is increasing in Bahrain as well. For example, e web-store, e store, Internet shop, web shop, web store, online store and virtual stores evokes the physical analogy of buying products/ services at a bricks and mortar retailer/shopping centre. This process is known as business to consumer [B2C] online shopping. When a business buys from another business it is known as [B2B] online shopping. In the present world largest online retailing corporations are Amazon.com, E Bay and Flipchart. Now companies are released and using effective marketing strategies analyze various factors to convert their potential consumers into active ones. The factors such as Information about the product, Ease of use, Satisfaction, Security/Privacy and Proper usage. In this paper we are trying to understand the preferences of consumer towards online shopping.

\section{Literature Review}

Internet shopping is still in development stage in Bahrain and limited research studies have been done. But various international studies have been undertaken in other countries.

Bellman et al (1999) examined various predictors for whether an individual will purchase online and they concluded that demographic variables such as education, age and income, have a modest impact on the decision of whether to buy online, where as the most important determinant of online shopping was previous behavior, such as earlier purchases. Therefore demographic factors are not much influenced on the purchases. According to Modahl 2000, Kotler and Amstrong (2000) stated that persons buying behavior is influenced by four key psychological factors i.e motivation, perception, learning and belief oriented attitude.

According to Ankit goel et al (2014) study found that service after sale provided by sellers (online shops) are quite excellent and what they assure makes buyers comfortable therefore, online shopping getting more success. Another piece of work from Ather Akhlaq et al (2014) concluded that technology is accepting theories of consumer it is helping researchers to know the demand from global online shopping.

Prashant singh (2014) made study on consumer's buying behavior on flipkart (India) and found that any e-tailer will be get success depends on fair policies, brand image and popularity. 
According to the Alina Babar et.al (2014), behaviour of the consumers regarding technology of internet is medium level and in other hand it should be free from physical and mental effort and even if online shopping not make any financial risk, there consumer attitude towards online shopping will be positive.

A piece of study carried out by Monsuwe et al (2004) collectively provides all the related literature review regarding the factors that drive consumers to shop online. As a further step, this paper encompasses the literature review regarding advantages, problems and consumers' expectations of online shopping, and examines the perceptions of adopters of online purchases compared to Internet users who preferred the traditional way of shopping.

Ernst and Young (2000) reported that Internet users purchased online because of good product selection, competitive prices, and ease of use, but were concerned about shipping costs, lack of opportunity to prior examining the products, as well as, the confidentiality of credit card and personal information.

Alka Kumawat and Tandon (2014) made study using questionnaire with 200 customers as a sample. The study reveled that customers are very satisfied towards online shopping because of the delivery system is working effectively therefore customers are doing shopping again and again.

\section{Research Gap}

The review of literature shows that most of the research on $\mathrm{E}$ shopping has been done in different countries by using different topics/areas. But much research has not been done in Bahrain and also on Bahraini Consumer preferences on E Shopping. Therefore the present study is an attempt in this direction.

\section{Objectives of the study}

The main objective of the present study is to analyze and find out the consumer preferences for choosing $\mathrm{E}$ shopping by the Bahraini consumers in Bahrain. However, the specific objectives of the study designed are as follows:-

* To know the factors which are influencing the Bahraini consumers.

* To investigate which profession of consumers prefers E shopping.

\section{Hypotheses}

The following hypotheses have been developed and tested.

* There is no positive relationship between factors of influencing and Bahraini consumers.

* There is no positive relationship between profession of the consumers and their shopping.

\section{Variables used in the study for analysis}

Profession of the consumer is taken as an independent variable, while factors are considered as dependent variable.

\section{Sample design}

The present study sample was collected from the consumers and buyer's of online shopping and it is based on convenience sample technique. Accordingly, 200 questionnaires were prepared with intention to get the required information to analyze the data and researchers sent questionnaires by $\mathrm{E}$ mail. The researchers also met the respondents and had informal discussion to get first hand information on consumer preference on $\mathrm{E}$ shopping. It was quit encouraging to the researchers that as many as 170 respondents have filled the questionnaire and returned them to the researchers. On scrutinizing, 150 respondents from different professions Via students [Number of respondents $(\mathrm{N})=50$ ], employees [Number of respondents $(\mathrm{N})=50$ ] and business persons [Number of respondents $(\mathrm{N})=50$ ] have filled the questionnaire completely that was found fit for analysis. Thus, all these 150 respondents have been selected again by adopting convenience sampling method. The responses given by them to the questionnaire are the basis for final analysis and findings.

\section{Response rate for the questionnaire from the respondents}

\begin{tabular}{|l|l|l|l|l|}
\hline Distributed & Returned Response & Percentage & Completed Response & Percentage \\
\hline 200 & 170 & 85 & 150 & 88.23 \\
\hline
\end{tabular}

\section{Scope of the study}

The present study has been exclusively made to understand and analyze the consumer preferences of buying through E shopping and to know professional status of E shopping of consumers in Bahrain.

\section{Method of data collection}

The study is basically an empirical in nature. The data for the present study is collected from both primary and secondary sources. Primary data are collected by administering a structure questionnaire among consumers on 
various dimensions such as students, business persons and employees and have been analyzed by using percentage method and presented in the form of Tables.

Limitations of the study

The present study has the following limitations as mentioned below

Being guided by the principle of brevity, the scope of the present study is restricted to cover only consumer preference on online shopping in Bahrain.

Analysis and Discussion

This portion intends to analyze which factors are influencing Bahraini consumers. For this Two variables such as independent and dependent variables are analyzed based on the opinions expressed by the respondents (i.e Students, Employees and Business Persons). The consumers and their designations are considered as independent variable, while the factors are considered as dependent variable for the analysis.

\section{Research objective}

To know which factors are influencing Bahraini consumers

Null Hypothesis

There is no positive relationship between factors of influencing and Bahraini consumers.

Table 1: Respondents' opinion on regarding online shopping site.

\begin{tabular}{|c|l|c|c|c|c|c|}
\hline \multirow{2}{*}{ SI No } & \multirow{2}{*}{ Profession } & \multicolumn{3}{c|}{ Opinion 150} \\
\cline { 3 - 7 } & & Search Engine & Television & Friends & Others & \\
\hline $\mathbf{1}$ & Students & 23 & 10 & 07 & 10 & 50 \\
& & $(15.33)$ & $(6.67)$ & $(4.66)$ & $(6.67)$ & $(33.33)$ \\
\hline $\mathbf{2}$ & Employees & 10 & 02 & 22 & 16 & 50 \\
& & $(6.67)$ & $(1.33)$ & $(14.66)$ & $(10.64)$ & $(33.33)$ \\
\hline $\mathbf{3}$ & Business Persons & 17 & 08 & 05 & 20 & 50 \\
& & $(11.33)$ & $(5.33)$ & $(3.33)$ & $(13.34)$ & $(33.33)$ \\
\hline $\mathbf{4}$ & Total & 50 & 20 & 34 & 46 & 150 \\
& & $(33.33)$ & $(13.34)$ & $(22.67)$ & $(30.66)$ & $(100)$ \\
\hline
\end{tabular}

Source : Data collected through questionnaire by the Researchers

Note : Figures in parentheses represent percentages to the respective vertical totals and horizontal grand total.

$\mathrm{N} \quad$ : Number of respondents

Table 1 portrays the profession-wise opinion of the respondents about the utilization of websites of online shopping. It is found that 50 (33.33 per cent) respondents out of 150 , selected have opined that 46 (30.66) per cent respondents feels that they use other websites for online shopping. On the whole it can be concluded that a majority of the respondents irrespective of their cadres are using websites for online shopping. Hence, there is evidence to reject the null hypothesis of due to lack of influence of websites on online shopping. In other words it may be constructed that there is a relationship between these two variables.

Table 2: Respondents' opinion on online shopping site

\begin{tabular}{|c|l|c|c|c|c|c|}
\hline \multirow{2}{*}{ Sl. No } & \multicolumn{1}{|c|}{ Profession } & \multicolumn{2}{|c|}{ Opinion 150} \\
\cline { 3 - 7 } & & E bay & Amazon & Homeshop & Other & Total \\
\hline $\mathbf{1}$ & Students & 28 & 13 & 06 & 03 & 50 \\
& & $(18.67)$ & $(8.66)$ & $(4.00)$ & $(2.00)$ & $(33.33)$ \\
\hline $\mathbf{2}$ & Employees & 10 & 12 & 18 & 10 & 50 \\
& & $(6.67)$ & $(8.00)$ & $(12.00)$ & $(6.66)$ & $(33.33)$ \\
\hline $\mathbf{3}$ & Business Persons & 15 & 10 & 06 & 19 & 50 \\
& & $(10.00)$ & $(6.67)$ & $(4.00)$ & $(12.66)$ & $(33.33)$ \\
\hline $\mathbf{4}$ & Total & 53 & 35 & 30 & 32 & 150 \\
& & $(35.34)$ & $(23.33)$ & $(20.00)$ & $(21.33)$ & $(100)$ \\
\hline
\end{tabular}

Source : Data collected through questionnaire by the Researchers total.

Note : Figures in parentheses represent percentages to the respective vertical totals and horizontal grand

Profession-wise opinion of the respondents about the browsing utilization of websites of various sites of online shopping of E bay, Amazon, Home shop and other details is shown in Table 2. It is found that 53 (35.34 per cent) respondents out of 150 selected have stated that $\mathrm{E}$ bay is being used more, 35 (23.33 per cent) respondents expressed that it is used, and 32 (21.33 per cent) respondents held that it is useful. 
Thus, it is evident that respondents' opinion on browsing frequency to do online shopping in E bay, Amazon and other sites are reported to be more in per centage.

Table 3 : Respondents' opinion on products and services provided by the online shopping providers.

\begin{tabular}{|c|l|c|c|c|c|c|}
\hline \multirow{2}{*}{ Sl. No } & \multirow{2}{*}{ Profession } & \multicolumn{4}{|c|}{ Opinion } & \multicolumn{2}{c|}{ Total } \\
\cline { 3 - 7 } & & Excellent & Good & Average & Poor & \\
\hline $\mathbf{1}$ & Students & 23 & 17 & 03 & 07 & 50 \\
& & $(15.34)$ & $(11.33)$ & $(2.00)$ & $(4.66)$ & $(33.33)$ \\
\hline $\mathbf{2}$ & Employees & 09 & 34 & 02 & 05 & 50 \\
& & $(6.00)$ & $(22.67)$ & $(1.33)$ & $(3.33)$ & $(33.33)$ \\
\hline $\mathbf{3}$ & Business Persons & 10 & 26 & 09 & 05 & 50 \\
& & $(6.66)$ & $(17.33)$ & $(6.00)$ & $(3.33)$ & $(33.33)$ \\
\hline $\mathbf{4}$ & Total & 42 & 77 & 14 & 17 & 150 \\
& & $(28.00)$ & $(51.34)$ & $(9.33)$ & $(11.33)$ & $(100)$ \\
\hline
\end{tabular}

Source : Data collected through questionnaire by the Researchers

Note : Figures in parentheses represent percentages to the respective vertical totals and horizontal grand total.

Table 3 incorporated the profession-wise opinion of the respondents about the product and services provided by the online shopping providers. It is found that 77 (per cent) respondents out of 150 selected have opined that providers of online shopping are good, 42 (28 per cent) respondents opined that it is excellent, followed by the 14 (9.33 per cent) to an average. Thus, it may be said that majority of the respondents opined that online shopping providers are providing good products and services.

Table 4 : Respondents' opinion on purchasing frequency on online shopping.

\begin{tabular}{|c|l|c|c|c|c|c|}
\hline \multirow{2}{*}{$\begin{array}{c}\text { Sl. } \\
\text { No }\end{array}$} & \multicolumn{2}{|c|}{ Profession } & \multicolumn{5}{|c|}{ Opinion } & \multirow{2}{*}{ Total } \\
\cline { 3 - 6 } & & $\begin{array}{c}\text { Once in a } \\
\text { Week }\end{array}$ & $\begin{array}{c}\text { Once in a } \\
\text { Month }\end{array}$ & $\begin{array}{c}\text { Once in a } \\
\text { Year }\end{array}$ & $\begin{array}{c}\text { More than } \\
\text { a year }\end{array}$ & \\
\hline $\mathbf{1}$ & Students & $\begin{array}{c}10 \\
(6.66)\end{array}$ & $\begin{array}{c}06 \\
(4.00)\end{array}$ & $\begin{array}{c}07 \\
(4.67)\end{array}$ & $\begin{array}{c}27 \\
(18.00)\end{array}$ & $\begin{array}{c}50 \\
(33.33)\end{array}$ \\
\hline $\mathbf{2}$ & Employees & 04 & 20 & 16 & 10 & 50 \\
& & $(2.66)$ & $(13.33)$ & $(10.66)$ & $(10.66)$ & $(33.33)$ \\
\hline $\mathbf{3}$ & Business Persons & 10 & 14 & 12 & 14 & 50 \\
& & $(10.66)$ & $(9.33)$ & $(8.00)$ & $(9.33)$ & $(33.33)$ \\
\hline $\mathbf{4}$ & Total & 24 & 40 & 35 & 51 & 150 \\
& & $(16.00)$ & $(26.66)$ & $(23.34)$ & $(34.00)$ & $(100)$ \\
\hline
\end{tabular}

Source : Data collected through questionnaire by the Researchers total.

Note : Figures in parentheses represent percentages to the respective vertical totals and horizontal grand

Table 4 shows profession-wise opinion of the respondents about the purchasing frequency on online shopping. It can further be found that 51 (34 per cent) respondents out of 150 selected have stated that they use to purchase any products online once in a year, 40 (26.66 per cent) respondents have stated that do online shopping once in month. It can be concluded that majority of the respondents are felt that they are involving in online shopping activity. 
Table 5: Respondents' opinion on category of products of purchasing on online.

\begin{tabular}{|c|c|c|c|c|c|}
\hline \multirow{3}{*}{ Sl. No } & \multirow{3}{*}{ Opinion } & \multirow{2}{*}{\multicolumn{3}{|c|}{ Profession }} & \multirow{3}{*}{$\frac{0}{\text { Total }}$} \\
\hline & & & & & \\
\hline & & Students & Employees & Business Persons & \\
\hline 1 & Apparels & $\begin{array}{c}00 \\
(0.00)\end{array}$ & $\begin{array}{c}14 \\
(9.33)\end{array}$ & $\begin{array}{c}07 \\
(4.66)\end{array}$ & $\begin{array}{c}21 \\
(14.00)\end{array}$ \\
\hline 2 & Health \& beauty & $\begin{array}{c}03 \\
(2.00)\end{array}$ & $\begin{array}{c}02 \\
(1.34)\end{array}$ & $\begin{array}{c}14 \\
(9.33)\end{array}$ & $\begin{array}{c}19 \\
(12.66) \\
\end{array}$ \\
\hline 3 & Consumer Electronics & $\begin{array}{c}27 \\
(18.00) \\
\end{array}$ & $\begin{array}{c}14 \\
(9.34) \\
\end{array}$ & $\begin{array}{c}11 \\
(7.33) \\
\end{array}$ & $\begin{array}{c}52 \\
(34.66) \\
\end{array}$ \\
\hline 4 & Books & $\begin{array}{c}10 \\
(6.67)\end{array}$ & $\begin{array}{c}04 \\
(2.66)\end{array}$ & $\begin{array}{c}03 \\
(2.00)\end{array}$ & $\begin{array}{c}17 \\
(11.33)\end{array}$ \\
\hline 5 & Computer \& Related & $\begin{array}{c}00 \\
(0.00)\end{array}$ & $\begin{array}{c}06 \\
(4.00)\end{array}$ & $\begin{array}{c}03 \\
(2.00)\end{array}$ & $\begin{array}{c}09 \\
(6.00)\end{array}$ \\
\hline 6 & Mobile Phones & $\begin{array}{c}00 \\
(0.00)\end{array}$ & $\begin{array}{c}00 \\
(0.00)\end{array}$ & $\begin{array}{c}06 \\
(4.00)\end{array}$ & $\begin{array}{c}06 \\
(4.00)\end{array}$ \\
\hline 7 & None of these & $\begin{array}{c}10 \\
(6.66)\end{array}$ & $\begin{array}{c}10 \\
(6.66)\end{array}$ & $\begin{array}{c}06 \\
(4.00)\end{array}$ & $\begin{array}{c}26 \\
(17.33) \\
\end{array}$ \\
\hline 8 & Total & $\begin{array}{c}50 \\
(33.33) \\
\end{array}$ & $\begin{array}{c}50 \\
(33.33) \\
\end{array}$ & $\begin{array}{c}50 \\
(33.33) \\
\end{array}$ & $\begin{array}{c}150 \\
(100) \\
\end{array}$ \\
\hline
\end{tabular}

Source : Data collected through questionnaire by the Researchers

Note : Figures in parentheses represent percentages to the respective horizontal totals and vertical grand total.

As per the details furnished in Table 5 it can explicitly be found that 52 (34.66 per cent) respondents out of 150 selected are purchasing consumer electronics products, 26 (17.33 per cent) respondents opined its use in this regards some other products and only 21 (14.00 per cent) respondents that they are purchasing other products.

Table 6 : Respondents' opinion on reasons behind for selecting online shopping.

\begin{tabular}{|c|l|c|c|c|c|c|}
\hline \multirow{2}{*}{ Sl. No } & \multirow{2}{*}{ Profession } & \multicolumn{3}{|c|}{ Opinion } & \multicolumn{2}{|c|}{ Total } \\
\cline { 3 - 7 } & & $\begin{array}{c}\text { Wide Variety } \\
\text { of Products }\end{array}$ & Less Prices & Save Time & Others & \\
\hline $\mathbf{1}$ & Students & 14 & 11 & 14 & 11 & 50 \\
& & $(9.33)$ & $(9.33)$ & $(9.34)$ & $(9.33)$ & $(33.33)$ \\
\hline $\mathbf{2}$ & Employees & 14 & 08 & 19 & 09 & 50 \\
& & $(9.33)$ & $(5.33)$ & $(12.66)$ & $(6.00)$ & $(33.33)$ \\
\hline $\mathbf{3}$ & Business Persons & 11 & 06 & 25 & 08 & 50 \\
& & $(9.33)$ & $(4.00)$ & $(16.66)$ & $(5.33)$ & $(33.33)$ \\
\hline $\mathbf{4}$ & Total & 39 & 25 & 58 & 28 & 150 \\
& & $(26.00)$ & $(16.67)$ & $(38.66)$ & $(18.67)$ & $(100)$ \\
\hline
\end{tabular}

Source : Data collected through questionnaire by the Researchers

Note : Figures in parentheses represent percentages to the respective vertical totals and horizontal grand total.

Table 6 reveals the details about the profession-wise opinion of the respondents about the reasons behind, for selecting online shopping. It is found that 58 (38.66) per cent) respondents out of 150 selected have opined that it saves the time, 39 ( 26 per cent) respondents opined that it displays wide variety of products. Thus, it is established that respondents' opinion on reason behind for selecting online shopping is stated to save time (58), and wide variety of products (39) respondents. 
Table 7: Respondents' opinion on mode of payment for online shopping.

\begin{tabular}{|c|l|c|c|c|c|c|}
\hline \multirow{2}{*}{ SI No } & \multirow{2}{*}{ Profession } & \multicolumn{3}{|c|}{ Opinion } & \multicolumn{2}{c|}{ Total } \\
\cline { 3 - 7 } & & Cash & Credit Card & Debit Card & All of these & \\
\hline $\mathbf{1}$ & Students & 06 & 25 & 19 & 00 & 50 \\
& & $(4.00)$ & $(16.67)$ & $(12.66)$ & $(0.00)$ & $(33.33)$ \\
\hline $\mathbf{2}$ & Employees & 05 & 30 & 05 & 10 & 50 \\
& & $(3.33)$ & $(20.00)$ & $(3.33)$ & $(10.66)$ & $(33.33)$ \\
\hline $\mathbf{3}$ & Business Persons & 04 & 35 & 08 & 03 & 50 \\
& & $(2.66)$ & $(23.33)$ & $(5.33)$ & $(2.00)$ & $(33.33)$ \\
\hline $\mathbf{4}$ & Total & 15 & 90 & 32 & 13 & 150 \\
& & $(10.00)$ & $(60.00)$ & $(21.33)$ & $(8.67)$ & $(100)$ \\
\hline
\end{tabular}

Source : Data collected through questionnaire by the Researchers

Note : Figures in parentheses represent percentages to the respective vertical totals and horizontal grand total.

Table 7 gives the details about profession-wise opinion of the respondents about the

payment mode for online shopping. It is found that 90 (60 per cent) respondents have stated that they are using credit card for payment, 32 (21.33 per cent) respondents have opined that they are using Debit card. In brief it can be concluded that majority of the respondents opined that Credit Cards and Debit cards are used more.

Table 8 : Respondents' opinion on product deliver after invoice

\begin{tabular}{|c|l|c|c|c|c|c|}
\hline \multirow{2}{*}{ SI No } & \multirow{2}{*}{ Profession } & \multicolumn{3}{|c|}{ Opinion } & \multirow{2}{*}{ Total } \\
\cline { 3 - 6 } & & $\begin{array}{c}\text { Within } \\
\text { Working } \\
\text { Days }\end{array}$ & $\begin{array}{c}\text { Within a } \\
\text { Week }\end{array}$ & $\begin{array}{c}\text { Within 15 } \\
\text { Days }\end{array}$ & $\begin{array}{c}\text { Within a } \\
\text { Month }\end{array}$ & \\
\hline $\mathbf{1}$ & Students & 04 & 03 & 20 & 23 & 50 \\
& & $(2.66)$ & $(2.00)$ & $(13.33)$ & $(15.33)$ & $(33.33)$ \\
\hline $\mathbf{2}$ & Employees & 04 & 15 & 26 & 05 & 50 \\
& & $(2.66)$ & $(10.00)$ & $(17.33)$ & $(3.33)$ & $(33.33)$ \\
\hline $\mathbf{3}$ & Business & 09 & 06 & 17 & 28 & 50 \\
& Persons & $(6.00)$ & $(4.00)$ & $(11.33)$ & $(18.66)$ & $(33.33)$ \\
\hline $\mathbf{4}$ & Total & 17 & 24 & 63 & 56 & 150 \\
& & $(11.34)$ & $(16.00)$ & $(42.00)$ & $(37.33)$ & $(100)$ \\
\hline
\end{tabular}

Source : Data collected through questionnaire by the Researchers

Note : Figures in parentheses represent percentages to the respective vertical totals and horizontal grand total.

Details about the profession-wise opinion of the respondents about the product delivery after invoice are given in Table 8. It is found that 63 (42 per cent) respondents out of 150 selected have stated that product will be deliver to the consumer within 15 days, 56 (37.33 per cent) respondents opined it arrived with in 15 days. It is, therefore, concluded that majority of the respondents felt that they receive the production on-time.

Table 9 : Respondents' opinion on quality of products in online shopping

\begin{tabular}{|c|l|c|c|c|}
\hline \multicolumn{2}{|c|}{ Profession } & \multicolumn{2}{|c|}{ Opinion 150} \\
\cline { 2 - 4 } Sl. No & & Yes & No & \multirow{2}{*}{ Total } \\
\hline $\mathbf{1}$ & Students & 42 & 08 & 50 \\
& & $(28.00)$ & $(5.33)$ & $(33.33)$ \\
\hline $\mathbf{2}$ & Employees & 40 & 10 & 50 \\
& & $(26.67)$ & $(6.67)$ & $(33.33)$ \\
\hline $\mathbf{3}$ & Business Persons & 33 & 17 & 50 \\
& & $(22.00)$ & $(11.33)$ & $(33.33)$ \\
\hline $\mathbf{4}$ & Total & 115 & 35 & 150 \\
& & $(76.66)$ & $(23.34)$ & $(100)$ \\
\hline
\end{tabular}

Source : Data collected through questionnaire by the Researchers total.

Note : Figures in parentheses represent percentages to the respective vertical totals and horizontal grand 
Table 9 demonstrates the details about the profession-wise opinion of the respondents about the quality of products in online shopping. It is found that 115 respondents representing 76.66 per cent have expressed yes. Thus, it is identified that respondent's opinion on quality of products in online is good (i.e Yes).

Table 10 : Respondents' opinion on replacement policy for defective products

\begin{tabular}{|c|c|c|c|c|}
\hline \multirow{3}{*}{ Sl. No } & \multirow{3}{*}{ Profession } & & \multicolumn{2}{|c|}{$N=150$} \\
\hline & & \multicolumn{2}{|c|}{ Opinion } & \multirow[t]{2}{*}{ Total } \\
\hline & & Yes & No & \\
\hline 1 & Students & $\begin{array}{c}45 \\
(30.00)\end{array}$ & $\begin{array}{c}05 \\
(3.33)\end{array}$ & $\begin{array}{c}50 \\
(33.33) \\
\end{array}$ \\
\hline 2 & Employees & $\begin{array}{c}35 \\
(23.34) \\
\end{array}$ & $\begin{array}{c}15 \\
(10.00) \\
\end{array}$ & $\begin{array}{c}50 \\
(33.33) \\
\end{array}$ \\
\hline 3 & Business Persons & $\begin{array}{c}21 \\
(14.00)\end{array}$ & $\begin{array}{c}29 \\
(19.33)\end{array}$ & $\begin{array}{c}50 \\
(33.33)\end{array}$ \\
\hline 4 & Total & $\begin{array}{c}101 \\
(67.33) \\
\end{array}$ & $\begin{array}{c}49 \\
(32.67) \\
\end{array}$ & $\begin{array}{c}150 \\
(100)\end{array}$ \\
\hline
\end{tabular}

Source : Data collected through questionnaire by the Researchers

Note : Figures in parentheses represent percentages to the respective vertical totals and horizontal grand total.

Table 10 portrayed the details about profession-wise opinion of the respondents about the replacement policy for defective products. It is found that 101 respondents expressed their opinion that they need policy. Therefore, it can be inferred that respondent's opinion on policy to be introduced (i.e Yes).

Table 11 : Respondents' opinion on choice of products for online shopping

\begin{tabular}{|c|c|c|c|c|c|c|}
\hline \multirow{3}{*}{ Sl. No } & \multirow{3}{*}{ Profession } & \multicolumn{5}{|c|}{$N=150$} \\
\hline & & \multicolumn{4}{|c|}{ Opinion } & \multirow[t]{2}{*}{ Total } \\
\hline & & Always & Mostly & Rarely & Never & \\
\hline 1 & Students & $\begin{array}{c}16 \\
(10.67)\end{array}$ & $\begin{array}{c}13 \\
(8.66)\end{array}$ & $\begin{array}{c}18 \\
(12.00)\end{array}$ & $\begin{array}{c}03 \\
(2.00)\end{array}$ & $\begin{array}{c}50 \\
(33.33)\end{array}$ \\
\hline 2 & Employees & $\begin{array}{c}11 \\
(7.34)\end{array}$ & $\begin{array}{c}23 \\
(15.33)\end{array}$ & $\begin{array}{c}14 \\
(9.33)\end{array}$ & $\begin{array}{c}02 \\
(1.33)\end{array}$ & $\begin{array}{c}50 \\
(33.33)\end{array}$ \\
\hline 3 & $\begin{array}{l}\text { Business } \\
\text { Persons }\end{array}$ & $\begin{array}{c}13 \\
(8.66)\end{array}$ & $\begin{array}{c}12 \\
(8.00)\end{array}$ & $\begin{array}{c}16 \\
(10.66)\end{array}$ & $\begin{array}{c}09 \\
(6.00)\end{array}$ & $\begin{array}{c}50 \\
(33.33)\end{array}$ \\
\hline 4 & Total & $\begin{array}{c}40 \\
(26.66)\end{array}$ & $\begin{array}{c}48 \\
(32.00) \\
\end{array}$ & $\begin{array}{c}48 \\
(32.00)\end{array}$ & $\begin{array}{c}14 \\
(9.33) \\
\end{array}$ & $\begin{array}{c}150 \\
(100) \\
\end{array}$ \\
\hline
\end{tabular}

Source : Data collected through questionnaire by the Researchers

Note : Figures in parentheses represent percentages to the respective vertical totals and horizontal grand total.

Table 11 displays the profession-wise opinion of the respondents about the choice of products in online shopping. It is found that mostly 48 respondents and rarely 48 respondents out of 150 selected have stated the choice of product in online shopping.

Thus, it is evident that majority of the respondents are can acquire more choices on online shopping.

Table 12 : Respondents' opinion on payback on purchased products

\begin{tabular}{|c|l|c|c|c|}
\hline \multicolumn{2}{|c|}{ Profession } & \multicolumn{2}{c|}{ Opinion } & \multicolumn{2}{c|}{ Total } \\
\cline { 3 - 5 } Sl. No & & Yes & No & \\
\hline $\mathbf{1}$ & Students & 24 & 26 & 50 \\
& & $(16.00)$ & $(17.33)$ & $(33.33)$ \\
\hline $\mathbf{2}$ & Employees & 33 & 17 & 50 \\
& & $(22.00)$ & $(11.34)$ & $(33.33)$ \\
\hline $\mathbf{3}$ & Business Persons & 28 & 22 & 50 \\
& & $(18.67)$ & $(14.66)$ & $(33.33)$ \\
\hline $\mathbf{4}$ & Total & 85 & 65 & 150 \\
& & $(56.66)$ & $(43.34)$ & $(100)$ \\
\hline
\end{tabular}

Source : Data collected through questionnaire by the Researchers

Note : Figures in parentheses represent percentages to the respective vertical totals and horizontal grand total. 
Table 12 explains about the profession-wise opinion of the respondents about the payback on purchased products. It is found that 85 respondents opined that they are getting back their purchased product amount. Thus, it can be concluded that respondents' opinion on this regard is good (i.e Yes).

Table 13: Respondents' opinion on spending amount on single product

\begin{tabular}{|c|c|c|c|c|c|}
\hline \multirow{3}{*}{$\begin{array}{l}\text { Sl. } \\
\text { No }\end{array}$} & \multirow{3}{*}{ Profession } & & \multicolumn{3}{|c|}{$N=150$} \\
\hline & & \multicolumn{3}{|c|}{ Opinion } & \multirow[t]{2}{*}{ Total } \\
\hline & & $\begin{array}{c}\text { Less than } 200 \\
\text { Bahraini Dinars }\end{array}$ & $\begin{array}{c}200 \text { to } 500 \text { Bahraini } \\
\text { Dinars }\end{array}$ & $\begin{array}{l}\text { More than } 501 \\
\text { Bahraini Dinars }\end{array}$ & \\
\hline 1 & Students & $\begin{array}{c}33 \\
(22.00)\end{array}$ & $\begin{array}{c}14 \\
(9.34)\end{array}$ & $\begin{array}{c}03 \\
(2.00)\end{array}$ & $\begin{array}{c}50 \\
(33.33) \\
\end{array}$ \\
\hline 2 & Employees & $\begin{array}{c}32 \\
(21.33) \\
\end{array}$ & $\begin{array}{c}12 \\
(8.00)\end{array}$ & $\begin{array}{c}06 \\
(4.00) \\
\end{array}$ & $\begin{array}{c}50 \\
(33.33) \\
\end{array}$ \\
\hline 3 & Business Persons & $\begin{array}{c}32 \\
(21.33) \\
\end{array}$ & $\begin{array}{c}14 \\
(9.34) \\
\end{array}$ & $\begin{array}{c}04 \\
(2.66) \\
\end{array}$ & $\begin{array}{c}50 \\
(33.33) \\
\end{array}$ \\
\hline 4 & Total & $\begin{array}{c}97 \\
(64.67)\end{array}$ & $\begin{array}{c}40 \\
(26.66)\end{array}$ & $\begin{array}{c}13 \\
(8.67)\end{array}$ & $\begin{array}{c}150 \\
(100)\end{array}$ \\
\hline
\end{tabular}

Source : Data collected through questionnaire by the Researchers total.

Note : Figures in parentheses represent percentages to the respective vertical totals and horizontal grand

Table 13 incorporated the profession-wise opinion of the respondents about the spending amount on single product. It is found that 97 respondents out of 150 have stated that their spending amount on single product is less than 200 Bahraini Dinars, 40 (26.66 per cent) respondents opined it to be in between of 200 to 500 Bahraini Dinars.

Thus, it is observed that majority of the Bahraini consumers are spending less than 500 Bahraini Dinars for every single purchase.

Table 14: Respondent's opinion in personal information security for online shopping

\begin{tabular}{|c|c|c|c|c|}
\hline & & & \multicolumn{2}{|c|}{$\mathbf{N}=150$} \\
\hline \multirow[t]{2}{*}{ Sl. No } & \multirow[t]{2}{*}{ Profession } & \multicolumn{2}{|c|}{ Opinion } & \multirow[t]{2}{*}{ Total } \\
\hline & & Yes & No & \\
\hline 1 & Students & $\begin{array}{c}30 \\
(20.00)\end{array}$ & $\begin{array}{c}20 \\
(13.33)\end{array}$ & $\begin{array}{c}50 \\
(33.33) \\
\end{array}$ \\
\hline 2 & Employees & $\begin{array}{c}13 \\
(8.66)\end{array}$ & $\begin{array}{c}37 \\
(24.67)\end{array}$ & $\begin{array}{c}50 \\
(33.33)\end{array}$ \\
\hline 3 & Business Persons & $\begin{array}{c}29 \\
(19.33)\end{array}$ & $\begin{array}{c}21 \\
(14.00)\end{array}$ & $\begin{array}{c}50 \\
(33.33)\end{array}$ \\
\hline 4 & Total & $\begin{array}{c}72 \\
(48.00)\end{array}$ & $\begin{array}{c}78 \\
(52.00)\end{array}$ & $\begin{array}{c}150 \\
(100)\end{array}$ \\
\hline
\end{tabular}

Source : Data collected through questionnaire by the Researchers

Note : Figures in parentheses represent percentages to the respective vertical totals and horizontal grand total.

Table 14 spell out the profession-wise view of the respondents in personal information security of the consumers. It is found that 78 respondents out of 150 opined that they are in-secure about their personal information, followed by 72 (48 per cent) respondents who have said that it is secure (i.e Yes). On the whole a majority of the respondents opined that online shopping is risk taking shopping in the sample respondents.

In this section, an attempt is made to know, which profession of consumers prefer to purchase in online shopping. For this two variables such as independent and dependent variables are analyzed based on the opinions expressed by the respondents (i.e Students, Employees and Business Persons). The consumers and their designations are considered as independent variable, while the preferences of the consumers are considered as dependent variable for the analysis.

\section{Research Objective}

To investigate which profession of consumers prefers E shopping.

\section{Null Hypothesis}

There is no positive relationship between profession of the consumers and their shopping. 
Table 15: Respondents' opinion on E shopping preferences

\begin{tabular}{|c|c|c|c|c|}
\hline & \multirow{3}{*}{ Profession } & & & \\
\hline \multirow[t]{2}{*}{ Sl. No } & & \multicolumn{2}{|c|}{ Opinion } & \multirow[t]{2}{*}{ Total } \\
\hline & & Yes & No & \\
\hline 1 & Students & $\begin{array}{c}41 \\
(27.33)\end{array}$ & $\begin{array}{c}09 \\
(6.00)\end{array}$ & $\begin{array}{c}50 \\
(33.33)\end{array}$ \\
\hline 2 & Employees & $\begin{array}{c}32 \\
(21.33)\end{array}$ & $\begin{array}{c}18 \\
(12.00)\end{array}$ & $\begin{array}{c}50 \\
(33.33)\end{array}$ \\
\hline 3 & Business Persons & $\begin{array}{c}28 \\
(18.66)\end{array}$ & $\begin{array}{c}22 \\
(14.66)\end{array}$ & $\begin{array}{c}50 \\
(33.33)\end{array}$ \\
\hline 4 & Total & $\begin{array}{c}101 \\
(67.33)\end{array}$ & $\begin{array}{c}49 \\
(32.66)\end{array}$ & $\begin{array}{c}150 \\
(100)\end{array}$ \\
\hline
\end{tabular}

Source : Data collected through questionnaire by the Researchers

Note : Figures in parentheses represent percentages to the respective vertical totals and horizontal grand total.

Table 15 displays the details about profession-wise opinion of the respondents about the E shopping preferences. It is found that 101(67.33 per cent) respondents out of 350 selected have stated that they are very much in favor of online shopping. From the responses and the percentage analysis, it is evident that majority of the respondents (i.e profession-wise) have expressed extreme good (i.e Yes) for online shopping. Hence, there is evident to reject the null hypothesis of lack of impact on online shopping. In other words it may be constructed that there is a relationship between these two variables.

\section{Findings of the study}

The data were analyzed using statistical tests (i.e percentage analysis) that have been described and the results drawn based on these tests are given below:

* Profession-wise, the percentage is high in utilization of search engine compared to other sites.

* Majority of the respondents are browsing E bay to purchase any product.

* Respondents marked very high per centage on products and services availability in online shopping.

* Most of the respondents are choosing consumer electronic products for online shopping.

* Percentage of consumers felt that online shopping saves the time and cost and their payment mode is credit card.

* Respondents agreed that, they are getting quality of products in online shopping.

* Most of the respondents are suggesting that E Tailors should implement payback policy. If there is payback policy the consumers will feel secured to spent Dinars.

* Majority of the respondents feel insecure about their personal information.

* As whole majority of the respondents are very enthusiastic to purchase products online.

\section{Suggestions of the study}

* To raise online shopping consumers, E-tailors must give advertisement via mobile, wireless devices.

* The E tailors have to attract more and more consumers by giving more options. Such as searching option, delivery and online payment and etc.

* The security issues i.e personal information still continues to be a major risk and In-secure (i.e PIN for credit card, Smart card and transactions. Therefore teach consumers to make transactions on secure internet connections.

* The E tailors should be made aware about the variety of products sale promotion schemes \& it will make online shopping attractive and popular among the buyers.

* If E tailors need online shopping success in Bahrain the spread of internet services should be increased.

* Majority of the online shopping portals are in English, it creates a big problem in front of the prospective buyers. In a country like Bahrain where English is not the mother tongue. Therefore websites should also have an option to view it in Arabic.

* E tailors have to design their own app for payment.

\section{Future directions for future research}

E shopping is an emerging area, especially in E buying and selling processes. Hence, there is a wide scope for further research in it by way of expending the same to different professions in other industries.

To make verify the results of the present study in a wider setting and wider acceptance, sample may be selected from Bahrain and GCC countries by selecting more number of respondents.

Further the same study may be replicated selecting different professionals that have not been included in the present study and by collecting data from large sample size. 


\section{Conclusion}

It is well known, the number of Internet users are growing day-by-day, meanwhile online shopping also increased. It is clear that direction of E-tailors in Bahrain looks very bright and futuristic. E-tailors have been facilitated to the consumers by providing best of the best product within the range of budget through saving their time and money. It is clear fact that, online shopping has become a part in the lives of many people in Bahrain, there are many reasons behind the increase of online shopping store, they offer many options in respect of products and easy payment mode etc, when compared to personal/direct shopping.

\section{References}

Alina Babar et al (2014) Factors Influencing Online Shopping Behavior of Consumers, Journal of Basic and Applied Scientific Research, Vol 4 (4) pp 314-320, ISSN 2090-4304.

Alka Kumawat and Tandon (2014) Factors Influencing Customer's Satisfaction Level Towards Online Shopping in Jaipur and Gurgaon, International Journal of Innovative Research and Development Vol 3 isse 4, pp 348-356, ISSN 2278-0211.

Ankit Goel and Parul Garg (2014), A Study on Consumer Preferences for E Shopping, International Journal of Applied Research in Engineering and Science (IJARES), Vol 1 Issue 1, ISSN 2347-9337.

Ather Akhlaq et.al (2014), Online shopping A Global Perspective, Journal of Basic and Applied Scientific Research, Vol 4 (5) pp 153-160, ISSN 2090-4304.

Bellman, S., Lohse, G. and Johnson, E. (1999), Predictors of online buying behaviour, Communications of the ACM, 42 (12), 32-38.

Ernst and Young (2000), 'Global Online Retailing,[Online], [Retrieved January 27, 2003],http://www.ey.com.

Kotler, P. and Armstrong, G. (2000), Marketing (5th ed.), Prentice-Hall: Englewood Cliffs, NJ.

Modahl, M. (2000) Now or Never: How Companies Must Change to Win the Battle for the Internet Consumer, Harper Business: New York, NY.

Monsuwe, T. P., Dellaert, B. and Ruyter, K.(2004) 'What drives consumers to shop online A literature review,' International, Journal of Service Industry Management, 15 (1), 102-121

Prashant singh (2014), Consumers Buying Behaviour Towards Online Shopping (A case study of Flipkart.com user's in Lucknow city), Journal of Research In Commerce and Management Vol 3, pp 27-34, ISSN 22771166. 